\title{
DIE BEVORDERING VAN GEESTESWETENSKAPLIKE STUDIE*)
}

Prof. dr. M. Elaine Botha, Dept. Filosofie en Wetenskapsleer, P.U. vir C.H.O.

Hierdie tema sou op 'n verskeidenheid van wyses aangepak kon word: Eerstens is dit moontlik om planne te bedink op grond waarvan die studentegetalle in die geesteswetenskappe verhoog sou kon word. Tweedens is dit moontlik om 'n soort wetenskaplike rasionalisasie te verskaf vir die feit dat die oënskynlik anachronistiese geesteswetenskappe nog steeds aangebied word in 'n tyd waarin die hele samelewing in die teken van die wetenskap en die tegniek staan. Dit sou natuurlik ook moontlik wees om die tema aan te pak vanuit 'n statistiese ontleding van die stand van die geesteswetenskappe en daardeur op tendense en ontwikkelingsrigtinge te dui. Natuurlik sou daar voldoende grond wees om ook die hele kwessie van die gebrekkige finansiering van die reesteswetenskappe aan die orde te stel en 'n pleidooi te lewer vir beter salariëring van geesteswetenskaplik-geskooldes, beter beurse vir studente in die geesteswetenskappe en beslis meer geleenthede vir navorsing in die geesteswetenskappe. Voorts sou die uiteindelike werksituasie van die geesteswetenskaplik-geskoolde in oënskou geneem kon word. Indien daar 'n oorskot van geesteswetenskaplik-geskooldes bestian, sou dit geremedieer moes word en indien daar ' $n$ tekort aan dergelike geskooldes sou bestaan, sou planne beraam moes word vir die aanmoediging van studie in hierdie rigting.

Die gedagte van "bevordering" in die tema van hierdie artikel word egter op 'n ander wyse geinterpreteer: Daarmee word bedoel die noodsaaklike skep van ruimte waarin die egte geesteswetenskaplike aanpak en vorming in die akademie tot sy reg kan kom. Die wyse waarop die tersa geformuleer is, dui op 'n behoefte, miskien selfs op 'n leemte in die universiteits- en akademiese opset. Verskillende vrae ontstaan wanneer gedink word oor die moontlike gronde en redes vir die onpopulariteit, gebrekkige diepte en ondoeltreffendheid van die die geestesweten skappe.

Daar skort kennelik iets met die geesteswetenskappe. Hoe is dit moontlik dat kennis wat so belangrik is, vir die mens reeds soveel beteken het en nog kan beteken so laag gewaardeer word in die prioriteiteskaal van die Westerse samelewing?

* Rede by geleentheid van die gradeplegtigheid van die Fakulteit Lettere en Wysbegeerte van die P.U. vir C.H.O. op 24 Maart 1980. 
* Lê dit aan die manier waarop die wetenskappe self bedryf word?

* Sou dit dalk geleë wees in die gebrekkige vorming van die student wat in die geesteswetenskappe studeer?

* Sou ons universitêre opset die skuld daaraan hê?

* Lê die probleem dalk by 'n samelewing waarin sodanige waardeverskuiwing plaasgevind het dat insigte, ideale, oortuiginge, kuns, letterkunde en musiek om maar nie te praat van geskiedenis en kultuur, uitgehol geraak het en verplaas is deur ander lewenswaardes?

Ten einde hierdie en ander vrae in perspektief te kry, is dit nodig om te kyk na die plek van die geesteswetenskappe binne die grense van die universiteit en sy kurrikulum en na die taak van die universiteit in die samelewing.

\section{Nadere omlyning van die geesteswetenskappe}

Die begrip "geesteswetenskappe" word gangbaar gebruik teenoor die "natuurwetenskappe" en dan word daarmee in die reèl bedoel die hele kompleks van wetenskappe wat op een of ander wyse met die studie van die mens of menslike handelinge, lewensuitinge en kultuur te make het.

Ná die eerste wêreldoorlog het veral in die V.S.A. die driedeling van die natuurwetenskappe, sosiale wetenskappe en "humanities" geleidelik ingeburger geraak. Die rede vir die ontwikkeling van die laasgenoemde been van die trits was die ontwikkeling van 'n nuwe tipe van aggressiewe sosiale wetenskaplike wat sy wetenskap wou uitbou na die voorbeeld van die natuurwetenskappe: objektief, neutraal en waardevry met 'n kenmerkende presiese en abstrakte benadering.

Teenoor hierdie groep "eksakte" sosiaal-wetenskaplikes het die beoefenaars van die tradisionele humaniora gestaan, w.o. die geskiedeniswetenskap, die tale en letterkunde, die kunste en die filosofie. Hulle het hulleself algaande van die ander twee wetenskapsgehele afgegrens as 'n groepering van wetenskappe wat minstens bereid was om te erken dat daar waardes van een of ander aard in hulle wetenskaplike werk inbegrepe was. Dié ontwikkeling word dan ook toegeskryf aan 'n bewuste reaksie op die eksklusiewe houding van die na-oorlogse sosiaal-wetenskaplikes met hulle pretensie van eksakte, neutrale kennis. 
In ons eie land het hierdie driedeling ook in die fakulteitsindeling van sommige universiteite ingang gevind, met daarnaas nog die terreine van ekonomie en regte wat, hoewel gangbaar gereken tot die geesteswetenskappe, tog ook aparte kennisgehele verteenwoordig.

Ilier word die begrip soos volg gedefinieer: Die hele veld van geesteswetenskappe wat gangbaar gestel word, in die literatuur teenoor die natuurwetenskappe, hoewel hierdie tweedeling op prinsipiële gronde aanvegbaar is.

Wil 'n mens kom tot 'n omskrywing van die geesteswetenskappe, dan blyk dit dat talle skrywers die geesteswetenskappe definieer aan die hand van die voorwerp van studie van die geesteswetenskappe, nl. die "gees" - in aansluiting by die bekende Phänomenologie des Geistes van Hegel. Die tweedeling word dan gefundeer deur 'n soort verdeling van die werklikheid in materie en gees, wat dan dikwels ook korreleer met die tweedeling tussen liggaam en siel. Omdat dergelike indelinge egter al gou as erg spekulatief gesien is, is die tweede pool van die tweedeling histories met 'n verskeidenheid van ander benaminge aangedui soos o.a. kultuurwetenskappe, sosiale wetenskappe, humaniora ens. (Meyer, 1969).

Dit is m.i. ontoereikend om die geesteswetenskappe primêr te omlyn aan die hand van die betrokke voorwerp van studie. Dit is voorts ook van die allergrootste belang dat die doel van die geesteswetenskappe duidelik gesien word: $\mathrm{Al}$ die geesteswetenskappe is fundamenteel gemoeid met die vrye of skeppende aktiwiteite van die mens en moet dus uiteindelik voer tot die insig in menslike denke, kennis en kultuurprodukte. Nieteenstaande hierdie feit is dit tog merkwaardig dat in soveel van die geesteswetenskappe die oorheersende beskouing van die mens ingeklee is in die idioom van die natuurwetenskappe. Hierdic stelling bring ons al dadelik by ' $n$ belangrike vraag wat van fundamentele belang is by die besinning oor die lewenskragtigheid van die geesteswetenskappe.

\section{Geesteswetenskappe geklee in die idioom van die natuurwetenskappe?}

Onder die bekoring van die natuurwetenskaplike wetenskapsmodel en die ideaal van neutrale, waardevrye en objektiewe wetenskap, het 'n groot aantal van die geesteswetenskappe hulle studieterrein begin ontgin juis na analogie van hierdie model. Hierdie idioom het die dominante idioom van haas alle wetenskappe geword. Miskien kom hierdie feit sprekend tot uitdrukking in die benoeming van skei- en natuurkunde aan ons middelbare skole as "wetenskap", terwyl aan alle ander vorme van kennis nie hierdie kwalifikasie toegeken word nie. Die middelbare 
skoolleerling word dan al gou ingelyf in 'n taal- en denkwyse waarin slegs dit as wetenskap beskou word wat "eksakte", "konkrete" "feite" is. Wetenskap word dan kortliks gedefinieer as die versameling en die verwerking van feite en die wyse van onderrig van die middelbare skole versterk hierdie patroon van denke. Hierdie opvatting van die aard van wetenskap word verder versterk in sy studentejare waar die student primêr met die handboek en die lesingmetode kennis maak en in hierdie proses wetenskap leer ken primêr in die gedaante van reeds geformuleerde en gesistematiseerde kennis.

Die student betree dus nou sy universitêre studie met min of meer die volgende indruk:

* Wetenskap (van watter aard ookal) het te make met beskrywing, feiteversameling en verklaring, hoofsaaklik deur die bepaling van oorsake.

* Enige wetenskap wat sy naam werd is, moet so min of meer die model van die fisika as wetenskap nastreef.

* Kennisvorming bestaan daarin dat soveel moontlik van hierdie deeleenhede van kennis geheumatig verwerk word.

* Onderrig bestaan uit so 'n breedvoerig moontlike uiteensetting van sodanige feite.

Studente verloor dan al spoedig belangstelling in daardie tipe van vakke wat nie presies op hierdie lees geskoei word of kan word nie en verdwyn al heel gou na die "eksakte" en "konkrete" feite-vakke.

Onder die verleiding van hierdie ideaal van "wetenskaplikheid" het menige geesteswetenskaplike alreeds geswig, met die gevolg dat nie slegs die wetenskaplike taalgebruik gereduseer is tot 'n tipe van operasionele begripsvorming nie, maar dic metode van kwantifisering en statistiese bewerking van empiriese gegewens gesien word as die enigste en juiste weg deur middel waarvan dit moontlik is om tot kennis van die mens en die mènslike samelewing en menslike handeling te kom. Insig (Verstehen) in die volryk diepte-dimensionele betekenis van die woord is verskraal tot die blote beskrywing van feite. Miskien word hierdie foutiewe instelling ook baie duidelik weerspieël in die afkeer van studente (en dosente) van insigvrae in die eksamen en die voorkeur vir "feite"-vrae by voorkeur deur middel van die metode van veelvuldigekeuse toetse. 
Hierdie instelling is egter ook in die hand gewerk deur die ontwikkelinge in die breëre samelewing en die dwingende invloed wat deur die dominante tegnies-wetenskaplike kultuur op die prioriteite van die universiteit en die samelewing uitgeoefen word. Laat ons dus eers vir 'n oomblik stilstaan by die belangrikste karaktertrekke van hierdie kultuur waarbinne die Christelike universiteit èn die geesteswetenskappe geroepe is om 'n taak te vervul.

\section{Die meta-tegnologie, kultuux en samelewing}

Dat die fenomenale ontwikkelinge in die natuurwetenskappe en die tegnologie vir die mensheid veel vooruitgang en seën inhou, is 'n voor-die-hand-liggende vanselfsprekendheid! Ons hoef maar te dink aan die beeldbuis, antibiotika, straalvliegtuie en industrieè en die rol wat hierdie dinge in die menslike lewe speel, om oortuig te raak van die positiewe kante van hierdie aspek van die kultuur.

Aan verskillende kante word ook alreeds die negatiewe en kwalike kante van die tegnologiese ontwikkelinge beklemtoon: Die mens is in staat om deur sy tegniek die natuurlike hulpbronne van die aarde uit te put; kan deur kernkrag wêrelddele vernietig en kan deur die afhanklikheid van olie die ekonomie van groot wêrelddele op sy knieë dwing. Grondliggend aan beide hierdie positiewe en negatiewe kante van die ontwikkelinge is die menslike beheersingsvermoë oor die werklikheid; 'n Geestesvermoë, wat gemotiveer word deur geestelike motiewe en dryfkragte en wat te make het met oortuiging van die mens, of as u wil, van die menslike gees.

Dwarsdeur die tegnies-wetenskaplike kultuur speel een motief 'n sentrale rol, $n$ l. die motief van menslike mag, en op 'n meer verborge vlak, die geloof en die vertroue in hierdie tipe van mag. Erens is die hele Westerse kultuur gebou en gegrondves op hierdie rotsvaste vertroue in die vermoë van die mens om deur sy eie tegniek en vernuf die wêreld waarin hy leef, te verbeter, te veraangenaam en miskien selfs in stand te hou, soveel so dat gesê sou kon word dat die tegnies-wetenskaplike wêreld 'n soort outomatisme besit: Die tegniek begin as die slaaf van die mens, maar werk algaande verslawing in die hand in die vorm van 'n proses van onomkeerbare afhanklikheid daarvan en matelose vertroue daarop.

In hierdie verband maak Leo Marx, professor in Engels aan die Amherst College in Massachusetts in die V.S.A. die bruikbare onderskeiding tussen drie vorme van tegnologie: 
* Eerstens tegnologie in die engste sin van die woord, ter aanduiding van al daardie vorme van kennis, vaardigheid en toerusting wat deur die mens vir praktiese doeleindes aangewend word.

* Tweedens daardie vorme van geburokratiseerde tegnologie wat dui op die burokratiese organisasie, waardeur praktiese kennis en vaardighede geadministreer moet word.

* Die derde alles-insluitende betekenis van die term is die van die meta-tegnologie. Hierdie begrip verwys na 'n reële gevaar, nl. die oorheersing van die lewe van die ganse menslike samelewing deur die denkstyl en die denkwyse wa: bevorderlik is vir die tegnologie in die enger sin van die woord. So 'n denkstyl impliseer onpersoonlike "piecemeal" analise, gestandardiseerde prosedure en die aanpassing van alle dinge - behalwe natuurlik die kontrolerende doeleindes van die samelewing self - aan daardie vorme van kennis wat vir presiese kwantifisering vatbaar is.

"Metatechnology, in short, is a name for the technological view of life raised to the highest power imagineable in our world - it is technology nationalized. It gives rise to the fatalistic idea that technology in the narrow sense, the practical application of scientific discovery, is the chief determinant of the course of contemporary history". Marx (1975, p. 9) praat in hierdie verband van die wesenlike gevaar van "technological totalitarianism".

By die lees hiervan kom die vraag na vore in hoe verre ons in die RSA in ons nasionale onderwysbeleidsvorming nie reeds op hierdie punt gevorder het nie. Wanneer die staatsonderwysbeleid die funksionering van die universiteit en die akademie meen te moet analiseer in daardie eenhede wat kwalifiseerbaar en op hierdie grond rasionaliseerbaar moet wees, moet die vraag gestel word hoe ver ons reeds op hierdie punt geswig het voor die verleiding van die meta-tegnologiese ideaal van die moderne samelewing.

Insiggewend was dit om te lees dat die aanvanklike oorsake van die studenteverset in die V.S.A. nie in die eerste plek teen die tegnologie as sodanig of die huwelik tussen akademie, groot politiek en die militêr-industriële apparaat gerig was nie, maar juis teen die tegnologie as dominante denkvorm waardeur ook die universiteit bedryf word ooreenkomstig die voorskrifte van die tegnoloë en die rekenaaroperateurs. So word die student niks veel meer nie as 'n stukkie rekenaarinligting wat so geruisloos moontlik ingepas moet word in die reeds geprogrammeerde sis- 
teem, wat op sy beurt weer die neerslag is van die beleidsbeslissinge onder die bekoring van die tegnologiese denkstyl van die moderne samelewing.

Miskien sou dit verstandig wees om rekening te hou met die feit dat die geesteswetenskappe 'n opdraande stryd te voer het teen hierdie dominante vooruitgangsgeloof van die moderne tegnologiese samelewing. Die geloof is gevoed deur die ideale van die natuurwetenskappe: Die ideaal van wetenskap wat voortskrei met behulp van die eksperimentle metode en die kwantifisering van kennis. Die wortelprobleem van die agterstand van die geesteswetenskappe is dan ook geleë in hierdie onvermoë van die geesteswetenskappe om juis op hierdie wyse tot kennis te kom en voorts ook in die gangbare vooroordele in die samelewing teenoor enige vorm van kennis wat nie kwantifiseerbaar en rekenariseerbaar is nie.

George Grant skets hoe die geesteswetenskappe dan tog wel 'n plekkie toegewys kry binne die groot konstellasie van die tegnologiese samelewing. Die natuurwetenskappe gee die toon aan in die samelewing, so sê hy, maar lewer eintlik slegs 'n klein deel van die beroepsmense op wat die mannekrag van die samelewing uitmaak. Die sosiale wetenskappe moet nou die sosiale ingenieurs en die sosiale tegnici oplewer wat die raderwerk van die samelewing so glad moontlik laat verloop, verkieslik met behulp van sosiale tegnologie soos psigologiese tegnieke, sosioterapeutiese tegnieke en langtermyn samelewingsbeplanning.

Wat bly nou vir die humaniora oor?

Die diensbaarheid aan die kultus van plesier, so beweer Grant (1975, p. 21 e.v.). Taal en letterkunde en die kunste word al hoe meer diensbaar aan die uitvoerende kunste en die vermaakindustrie.

Indien hierdie tekening van die bedreiging deur die meta-tegnologiese instelling juis is, dan hou dit beslis verreikende konsekwensies in vir die beoefening van die geesteswetenskappe, maar ook vir die rol van die universiteit in die samelewing. Of die geesteswetenskappe in die tipe van tegnologiese vooruitgangskultuur van ons tyd nog enige rol te vervul het, hang saam met die fundamentele beskouing wat gehuldig word m.b.t. die sin van die tegnies-wetenskaplike kultuur. Natuurlik is die studie van die geesteswetenskappe 'n anachronisme in 'n wêreld wat slegs glo in die matelose en grenslose uitbreiding van tegnologiese vooruitgang.

Die voorspelbare eindproduk van hierdie ontwikkelinge is die Multiversiteit. 
Die multiversiteit: Die akademie as diensstasie van die meta-tegnologiese gemeenskap

In 'n radikaal bewoorde pleidooi vir die behoud van die outonomie en die selfstandigheid van die akademie, skryf Roszak (1967) oor die gevolge van die "corrupted ideals of service and scholarship" wat die Amerikaanse universiteitswese in 'n krisis gedompel het. Roszak maak in sy artikel onder die sprekende tema van "academic delinquency" die snydende verwysing na wat hy noem die "service station ideal" van hoër onderwys wat saam met die ideaal van streng "Wissenschaft" - 'n ideaal wat deur die Amerikaanse akademici in Duitsland verwerf is - gevoer het tot die impasse waarin die Amerikaanse universiteitswese hom bevind.

Die impasse, so sê hy, het dan ook 'n naam gekry: En die naam van hierdie impasse?

\section{Die multiversiteit}

Twee teenoormekaarstaande ideale het so tot 'n gemeenskaplike resultaat gevoer. Die ideaal van diens aan die gemeenskap het $0 . \mathrm{m}$. van die absurde gevolge gehad soos die toekenning van Baccalaureate in has enige denkbare spesialiseringsrigting van "boy scouting" tot hotelbestuur.

"It meant in brief, cloaking in all the glamour and prestige of the higher learning whatever form of low-level training or ordinary entertainment the "community" felt it needed" (1967, p. 8).

Die multiversiteit het so geword ". . . the school which teaches ... anything we can get anybody to pay for" (waarby uiteraard ook noodsaaklike en waardevolle kennis inbegrepe was). Die diensideaal het gelei tot 'n kritieklose bereidwilligheid om enigiets aan te bied in die universiteit waarvoor maar geld te vinde sou kon wees, terwyl die Wissenschaftsideaal, die ideaal van suiwer wetenskap, gelei het tot die instelling dat die akademie hom met suiwer wetenskap moet besig hou wat nie betrokke is by die problematiek van die dag nie.

Wat was nou die resultaat van hierdie skisofrene instelling van die universiteit?

Enersyds dankbare diensbaarheid aan die ideale van die gemeenskap (en die ideale is sterk gemotiveer deur die vooruitgangsgeloof van die tegnies-industriële same- 
lewing) en anciersyds koue kritieklose afsydigheid t.o.v. die mees brandende vraagstukke van die dag. (Hy verwys na Viëtnam)

Kostelik stel Roszak (1967, p. 20) dit soos volg: "The world-as-it-is is becoming increasingly generous with its academics. So it is that academics, like technicians agree to prepare and equip the young to take their place in the world-as-it-is". Dit is duidelik dat dit vir Roszak in die laat sestigerjare in Amerika gegaan het om die gebrek aan sosiale betrokkenheid van die universiteit; dat hy veral worstel met die duidelike passiewe instelling van die sg. "adjustment university" wat eenvoudig bereid is om aan die kontoere van die bestaande orde te konformeer omdat dit sy bestaan en voortbestaan sanksioneer. Hy propageer, as radikale akademikus, die noodsaak van die "critical university"; énn wat radikaal-krities teen die grein van die bestaande orde in bereid sal moet wees om sy wetenskapstaak te volvoer. Hy bied ook 'n filosofiese rasionalisering hiervoor aan: 'n Nuwe intellektuele ideaal sou die universiteit moet motiveer, nl. een warin die tekortkominge van sowel die ideaal van gemeenskapsdiens en van suiwer wetenskapsbeoefening, oorbrug word. Vir hom is dié ideaal die een wat die Franse Ensiklopedikte gemotiveer het, nl. die reg tot soewereine kritiek met sy bevraagtekening van alle gesag, voorregte en tradisie.

Hoewel Roszak ons help om te verstaan wat die uiteindelike konsekwensies van die gemeenskapsdiens-ideaal en die suiwer wetenskapsideaal na lei, is dit moeilik om hom in sy pleidooi vir 'n radikaal sosiaal-betrokke wetenskap na te volg. Tog is dit duidelik dat die twee ideale waarteen hy hom verset, onherroeplik voer tot 'n gemaksugtige en behaaglike konformisme aan die bestaande orde wat geleidelik voer tot diensbaarheid aan die "wêreld-soos-dit-is", eenvoudig omdat hierdie "wêreld-soos-dit-is" die bestaan van die universiteit finansieel en andersins moontlik maak.

Die belangrike vraag wat hieruit voortvloei is uiteraard in hoeverre hierdie toedrag van sake nie reeds kenmerkend geword het van die Suid-Afrikaanse universitêre situasie nie. Die sleutel om hierdie vraag te beantwoord, is die kurrikulum van die universiteit (of in die geval van die geesteswetenskappe, van die fakulteit).

\section{Die kurrikulum in diens van die tegnologiese orde?}

Die sleutel tot die ontsluiting van die onderliggende waardesisteem van 'n universiteit en/of enige akademiese instelling - is die kurrikulum. Hierdeur word die karakter van die universiteit bepaal in 'n veel meer beslissende sin as deur die struk- 
tuur van die universiteit, sy sosiale organisasie of sy doseermetodes. In die gangbare opset van universiteit en samelewing verteenwoordig die kurrikulum dit wat deur die dominante groepe in die samelewing as belangrik geag word om te weet. Die leidinggewende groepe van 'n samelewing neem die beleidsbeslissinge wat die hoofdoelwitte van die samelewing beliggaam. In die Westerse samelewing het die dinamiek van die tegnologie geleidelik die dominante doelwit geword, omdat die ideaal van die beheersing van die werklikheid gesien is as een van die mees sentrale, rigtinggewende sake van die kultuur. Sou 'n mens die bestuurder van 'n groot industrie, die vakbondleier, die boer, die politikus, die staatsdiensamptenaar en die universiteitsadministrateur vra na die sin van hulle onderskeie beroepe, dan sou die antwoord gemeenskaplik wees: Die verwerwing van beheer oor die domein waarbinne hulle werksaam is. Die deursnee mense in hierdie rigtinge onderskryf êrens die fundamentele geloof van die moderne samelewing in die mag van die beheersing van die werklikheid, wat ons miskien beter leer ken het in die vorm van die ongebreidelde vooruitgangsgeloof ... en die hoofdoelwit van die kurrikulum van die modeme universiteit skyn te wees die voorbereiding van mense wat die sentrale funksies van ' $n$ samelewing in die greep van hierdie geloof sal kan inneem. Die proses vind sy neerslag in die tendens tot professionalisering.

Word hierdie verskynsel gekoppel aan die tendens tot toenemende spesialisasie binne die wetenskappe self, dan word dit verstaanbaar waarom die universiteitsfakulteite ook in 'n toenemende mate die beeld van fragmentarisering vertoon. Dissiplines en deeldissiplines in die vorm van "piecemeal" brokkies kennis, so sterk moontlik gerig op beroepsbruikbaarheid, skyn die dominerende tendens te wees.

Vakwetenskaplike stof word algaande al hoe meer gedifferensicerd en gespesialiseerd, sodat die universiteit wat sy naam werd is, al hoe meer deelgebied van kennis aanbied met die gevolg dat 'n komplekse verskeidenheid van hiper-gespesialiseerde kundiges die universiteit bevolk. Hierdie spesialiste moet egter weer op hulle beurt 'n al hoe wyer wordende spektrum van beroepe bedien omdat die moderne samelewing nou eenmaal van sy werknemers 'n al hoe groter hoeveelheid basiese kennis verg (Grant, 1975).

Hierdie opset skep nogal 'n dilemma vir sowel die student en die dosent. Probeer $u$ nou indink in die posisie van die dosent wat geleidelik leer verstaan het dat hy slegs as ' $n$ goeie en deeglike navorser geag word in die kringe van sy vak indien hy so gespesialiseerd moontlik navorsing doen en publiseer. Sy dagtaak bestaan egter uit die doseer van 'n groot hoeveelheid en verskeidenheid decldissiplines van 
sy vak aan studente komende uit 'n wye verskeidenheid van beroepsverwagtinge met een gemeenskaplike kenmerk nl. 'n behoefte aan kennis in die vorm van nuttigheidsmodules, kitsklaar berei en voorverpak vir konsumpsie met die oog op professionele behoeftes. Die effek van hierdie situasie is redelik voorspelbaar: Gefrustreerde dosente en verveelde studente en nog meer veeleisende beroepsinstansies ... Hierdie is natuurlik nie omstandighede wat slegs eie is aan die geesteswetenskappe nie; inteendeel.

George Grant stel onomwonde sy eie uitgangspunt m.b.t. kurrikulum: As ons aan die moderne universiteit as vrye mense werksaam wil wees, sal oordele gevel moet word m.b.t. die wese van die universiteit: sy kurrikulum. Indien sulke beslissinge meer is as 'n blote haarklowery oor detail, dan moet dit gebaseer wees op dit wat ons ag die sin van die menslike lewe te wees en wat diensbaar kan wees in die proses van die selfverwesenliking van die mens en die rol wat hoër onderwys in hierdie proses kan speel. Of ons as Christene die fundamentele vooronderstelling ten grondslag aan die universiteit en sy kurrikulum op presies dieselfde wyse sal formuleer, is 'n ope vraag. Tog kan Grant se analise ons help om ook die vinger te le op een van die swak plekke in die Suid-Afrikaanse universiteitswese.

In die lig van die voorafgaande uiteenstetting ontstaan die vraag of daar nie dalk reeds sprake is van ontwikkelinge in die rigting van 'n "Christelike multiversiteit" nie. Hiermee word bedoel die reële moontlikheid dat ook 'n Christelike universiteit geleidelik homself sou kon bevind in die drukgang van die dominante tendense wat die rigting bepaal van ons al hoe vinnig sekuler wordende maatskappy. Hoeveel van die onkritiese diensideaal en die steriele suiwer wetenskapsideaal het nie miskien al deel geword van die opset van die Christelike universiteit nie? Hiermee kom ons by die sentrale vraag wat die Christelike universiteit seker vir homself sal moet beantwoord wanneer daar besin word oor die rol wat die geesteswetenskappe behoort te speel in die studie van 'n wêreld wat aan God behoort.

\section{Die rol van die geesteswetenskappe aan 'n Christelike universiteit}

Watter tipe van toerusting kan juis die geesteswetenskappe bied aan die jeug wat geroepe is om in hierdie wêreld 'n unieke styl van lewe en denke te openbaar? Kernagtig sou ek wou sê dat geesteswetenskaplike studie aan 'n Christelike univer siteit tot taak het die vorming en die voorbereiding van die student vir 'n lewe uit die geloof te midde van die optrede en die denke van die mens in die moderne samelewing en kultuur. Hiervoor is 'n absolute voorvereiste die noodsaak dat die student die samelewing waarbinne hy geroep gaan word om hierdie lewe-in-die- 
geloof te voer, sal verstaan. Hy sal dus sowel die bronne en die wortels, die waardes, ideale en motiewe van die samelewing moet leer ken, maar hy sal ook 'n styl van profeties-kritiese onderskeidingsvermoë moet aanleer ... 'n onderskeidingsvermoë wat nog steeds sal funksioneer wanneer sy vakwetenskaplike kennis verouderd en uitgedien is.

'n Noodsaaklike voorwaarde waaraan voldoen moet word alvorens hierdie taak werklik ten uitvoer gebring sal kan word, is die ontworsteling van die geesteswetenskappe aan die dominante denktrant van die natuurwetenskappe en die loswikkelinge uit die wurggreep van professionalisasie en spesialisasie. Sodoende sal daar ruimte kom vir wat deur ons Calvinistiese geesverwante in die V.S.A. genoem word "disinterested theoretical inquiry" (Calvin College, 1970). Die regverdiging hiervoor bestaan daarin dat die geesteswetenskappe tot taak het die vorming en die skoling van die student se onderskeidingsvermoë tot 'n verantwoorde wetenskap. like denkwyse waarvan die primêre doelwit is dat die student 'n visie verwerf van wat die Koningskap van Christus op alle terreine sou kon beteken. Christelike wetenskapsboefening en daarmee saam die beoefening van die geesteswetenskappe het te make met 'n pertinente roeping-in-eie-reg. Dit mag nie bloot funksioneer as deurgangspoort en kanaal vir beroepsopleiding nie. Beroepsgerigte wetenskaps. beoefening is tot 'n sekere hoogte in teenspraak met mekaar.

Geesteswetenskaplike studie moet die student toerus met 'n begrip vir dic mens, die geestelike dryfkragte wat die menslike lewe rigting gee en stuur en die onderliggende ideologieë waardeur die geestesprodukte van die mens gedra word. Hieraan het die natuurwetenskaplike student net so 'n groot behoefte as die geesteswetenskaplike student, sodat die vraag ontstaan of dit nie dalk tyd geword het dat die geesteswetenskappe sy reg om hierdie tipe van skoling ook aan die natuurwetenskaplike te gee, sal opeis nie!

In die verband sou ook die volgende enkele moontlike groeipunte vir die geesteswetenskappe in die lig van die voorafgaande uiteensetting en kritiek aandag kon geniet.

Groeipunte vir die geesteswetenskappe

Wanneer die universiteit nie die moed het om uit die gevestigde keursly! van die tweedeling van natuur- en geesteswetenskappe te breek en ruimte te skep vir 'is meer algemene vorming van beide die natuurwetenskaplike en die geest scten. skaplike student nie, gaan die geesteswetenskappe die stryd me-...lik verloor. Sou 
dit nie oorweeg kon word om die huidige tendens in die rigting van spesialisasie aan die universiteite hok te slaan deur die instelling van 'n algemene vormingsjaar op die voorbeeld van die Amerikaanse "liberal arts" kurrikulum in die tradisie van die sg. "general education" nie? Hierdie kurrikulum sluit 'n kern van vakwetenskappe in uit die hele spektrum van sowel natuur- as geestewetenskappe.

Die Amerikaanse "general education"-opset het o.m. ten doel om aan die studente wat aan “college" studeer 'n gemeenskaplike opvoedkundige ervaring te verskaf met behulp waarvan hy beter toegerus sou wees om die verlede te interpreteer, die toekoms te beoordeel en 'n mate van konseptuele of gedissiplineerde begrips. vorming en denkstyl te verskaf waarmee die student in staat sou wees om allerhande nuwe vorme van kennis waarmee hy gekonfronteer word, te hanteer. Die grondprobleem waarmee in die hoër onderwys geworstel is, is die vraag hoe 'n student toegerus kon word in 'n wêreld waarin die kennis wat hy tans besig is om op te doen binne die tydsbestek van 25 jaar volstrek verouderd sou wees.

Die verskillende "general education"-programme aan die Amerikaanse kolleges het veral ten doel gehad om aan die student 'n duidelike beeld te gee van wie hy self is, waar hy en sy kultuur vandaan kom en ook om aan hom die metodologiese toerusting te verskaf met behulp waarvan hy met nuwe vorme van kennis sou kon omgaan. Vir hierdie doel is die student ingelei in 'n leesprogram wat die belangrikste "great books" verteenwoordigend van die hoogtepunte van menslike denke en kultuuruitinge dek. Hierdie "general education" programme aan Columbia, Chicago en Harvard het as hoofdoelwit gehad: die bevryding van die student uit die begrensing van sy eie opvoedingsmilieu, die begeleiding in die proses van self-ontdekking deur die aankweek van die bewussyn van tradisie en om hom te konfronteer met ' $n$ begrip van die onderlinge samehang van kennis.

Bell (1966, p. 51) identifiseer vier werkprinsipes en vooronderstellings wat aan hierdie programme gemeenskaplik was:

* Die behoefte in die Amerikaanse samelewing aan 'n eenheidsband, sodat die student tot die besef van 'n gemeenskaplike taak en doelwit sou kom. Dié doelwit sou in die begrip konsensus saamgevat kon word.

* Die tweede doelwit was die poging om die student bewus te maak van die geskiedenis van die Westerse samelewing ten einde sy horison te verbreed en om hom bewus te maak van die telkens terugkerende morele en politieke porbleme van die mens in die samelewing. Dié ideaal sou in die begrip burgerskap 
saamgevat kon word.

* Die "liberal arts college" se bedoeling was om die hele tendens tot spesialisering, so kernmerkend van die navorsing en wetenskapsbeoefening van die universiteitswese, teen te werk in die teken en die ideaal van "humanitas".

* Die aksent was dan ook sterk geplaas op die noodsaak om die sterk gedifferensieerde wetenskapsgeheel deur middel van interdissiplinêre kursusse saam te bind.

Die filosofiese wortels van hierdie opvoedkundige ontwikkelinge in die VSA is seker nie kongruent met dié van 'n Christelike universiteit nie, maar hierdie praktyk is op vele punte navolgenswaardig: Eerstens omdat daardeur 'n eenheidsgrondslag in die opvoedkundige onderbou van die student gelê word, voordat die proses van spesialisasie en professionalisering 'n aanvang neem en tweedens omdat hier, vanuit 'n weliswaar humanistiese motivering, gekies word vir die voorbereiding van die student vir 'n plek binne die kultuur en die samelewing waarbinne hy geroep word om 'n bydrae te lewer.

'n Christelike "general education" opset sou seker pertinent ander beklemtoninge en prioriteite hê, waarvan die belangrikste seker sal wees die feit dat die Christelike Universiteit die vorming van die student met die oog op sy taak in die Koninkryk van God sal wees - en hierdie tipe van vorming kan dikwels dwars. en reglynig ingaan teen die grein van die wêreld-soos-dit-is.

'n Tweede voorstel wat oorweeg sou kon word is die instelling van inter-en multidissiplinêre kursusse. Sou dit nie moontlik wees nie om die proses van spesialisasie op geestewetenskaplike terrein teen te werk deur die instelling van meer geleenthede tot interdissiplinêre werk - desnoods oor die grense van die gevestigde fakulteite heen. Die middeleeuse konsepsie van die eenheid van die wetenskappe sal ons waarskynlik nie maklik weer in die moderne universiteitsituasie kan haal nie, maar sou 'n interdissiplinêre benadering nie ruimte bied vir die geestewetenskappe om hulle eie unieke bydrae te lewer nie en deur hierdie bydrae ook die eensydige verscientifisering van die benadering van probleme teen te werk?

'n Derde voorstel wat in die massa literatuur oor hierdie onderwerp aangetref word, is die van die bekende Rooms Katolieke kultuurfilosoof Christopher Dawson (1961 en 1962) wat voorstel dat slegs 'n studie van die wortels en oorspronge van die Christelike Kultuur in staat sou wees om die samebindende faktor te verskaf 
wat die desintegrasie van die gebou van die wetenskap en die bedreiging van die sekularisme van ons kultuur te kan teenwerk.

Die vraag ontstaan of die studie van dic geesteswetenskappe nie ook daardeur sterk bevorder sou word wanneer die universiteite onderling en ook moontlik intern tot 'n duideliker prioriteitsbepaling sou kom nie. Moet die feit dat elke Suid.Ifrikaanse universiteit ten alle koste alle fakulteite moet herberg, nie op die lang duur tot ernstige verskraling van die kwaliteit van akademiese werk lei nie? Is dit nie so nie dat die twee prestige fakulteite van die universiteite nl. ingenieurswese en die mediese fakulteit, nie geesteswetenskappe is nie? Die vraag ontstaan of die Suid-Afrikaanse universiteitswese nie dringend moet besin oor die differensiasie van opleidinge nie. Dit lyk na 'n verspilling van geld en kragte wanneer ten alle koste personeel en fasiliteite daargestel moet word vir elke moontlike soort opleiding op elke kampus in die land. Waarom sou enkele universiteite nie kon besluit om hulle primer op geestewetenskaplike navorsing toe te la nie en dan onder meer daartoe oorgaan om 'n kurrikulum met 'n duidelik geestewetenskaplik georiënteerde kern van kursusse aan te bied wat aan die student die noodsaaklike algemene wetenskaplike vorming sal bied wat as gevolg van die genoemde tendense verlore gaan.

Dat hierdie en ander moontlike groeipunte vir die geesteswetenskappe gedra sal moet word deur 'n sterk fakultêre infrastruktuur, is bykans voor-die-hand-liggend. Daarom dan ook ten slotte enkele opmerkinge oor die fakultêre infrastruktuur waardeur geesteswetenskaplike studie bevorder sal word. Die aksent val nou veel sterker op die studie as op die geesteswetenskappe.

\section{Infrastrukturele knelpunte}

Christelike akademiese werk is werk-in-gemeenskap. Dit moet gedra word deur die aanwesigheid van 'n aktief werksame akademiese gemeenskapsgees. As enige vorm van egte navorsing gestimuleer wil word, dan is aan die Christelike universiteit die essensiële voorwaarde daarvoor die bestaan van 'n egte gemeenskapsgees. Wanneer dosente onderling nooit tot werklike gesprek oor die fundamentele vrae van hulle vakke kan kom nie, hetsy weens oorwerk, oorvermoeidheid of belangeloosheid en traagheid, dan skort daar jets heel ernstigs in die akademiese opset. Wanneer die struktuur van die wetenskaplike werk van die student sodanig is dat hy nooit tot egte studie kan kom nie, maar hoogstens een of twee maal per jaar homself moet wy aan 'n "swot" sessie waarin hy sy geheuevermoë, net soos die swaar corwerkte fotokopieerapparaat van die biblioteek, aan 'n marathonsessie 
onderwerp, dan is dit begryplik dat talle studente ten spyte van akademiese studie aan die universiteit, heel weinig egte akademiese vorming ondergaan.

Miskien moet maar geswyg word oor die doseerlas van dosente wat versprei is oor soveel deelgebiede van sy vak dat hy uiteindelik moet ontdek dat die minimale grens van sy onkunde die maksimale grens van die kennis van die student word... Sou hierdie faktore iets te make hê met die feit dat die lewendige vonk van besieling wat absoluut essensieel is in die motivering tot egte studie en navorsing in die geesteswetenskappe ontbreek?

'n Duidelike beeld van hierdie roeping van die geesteswetenskappe het ook konsekwensies vir die wyse waarop die kurrikulum gestruktureer word, maar ook baie duidelike konsekwensies vir die wyse waarop die inhoud van die onderskeie sillabusse geformuleer word. Dan is nie in die eerste plek die voorskrifte van die potensiële werkgewers die leidraad by die bepaling van die inhoud van die kurrikulum en die sillabus nie, ook nie die krampagtige poging om die hele spektrum van die vak binne die bestek van twee of drie jaar studie aan die student op te dring nie, maar die vraag: Watter fasette van die dissipline moet die student bemeester indien hy as geesteswetenskaplik geskoolde toegrus moet word met 'n akademiese ervaring wat hom 'n geestelik verrykte mens maak, beter geslyp en beter gevorm in sy oordeelsvermoë met die oog op sy taak in die koninkryk van God.

Dit het sekerlik ook konsekwensies vir die inrigting van die klassituasie en die didaktiek. Dan is die primêre vraag nie wat die finansieel-rasionele aantal studente is wat 'n klas moet bevolk nie, maar die vraag hoe groot die groep moet wees om 'n optimum leerproses in die betrokke vak moontlik te maak. Hierdie opmerking sny na twee kante toe: Na die kant van diegene wat meen dat op statistiese of watter grond ookal die ratio van soveel studente per dosent bepaal moet word, maar ook na die kant van diegene wat toelaat dat klasse uitgroei na monsteragtige proporsies waarin die dosent slegs "geleentheidsredenaar" word en die student in die proses aan minimale egte skoling onderwerp word.

Wil ons geesteswetenskaplike studie in die egte sin van die woord bevorder, is dit nodig om hierdie akademies-inflasionêre tendense duidelik aan die kaak te stel. Ons leef in 'n droomwêreld as ons dink dat hierdie faktore van ondergeskikte belang is. Dit sou moontlik wees dat ons groot getalle geesteswetenskaplik geskoolde graduandi aan ons universiteite oplewer, sonder dat die kwaliteit van die wetenskaplike vorming wat hulle ondergaan het werklik op peil is. 
Natuurlik is dit 'n onbegonnc taak vir 'n universiteit om 'n samelewing en onderwyssisteem te reformeer. Dit is bykans ondenkbaar dat 'n universiteit in die stroomversnelling van die moderne samelewing en kultuur en onderwys inspring en sê: "Ek is 'n damwal ..."

\section{Ten slotte}

Ons is tog nie so seker dat hierdie taak vanselfsprekend onmoontlik is nie. In die historiese geestesoog staan 'n klein geboutjie in Burgersdorp met 'n enkele dosent en 'n handjievol studente... Idealiste ...?

Vir die akademiese maghebbers van daardie tyd moes dit maar 'n patetiese poging gewees het. Sou die rare groepie idealiste ooit iets van hulle oortuiginge geloofwaardige gestalte kon gee? het die tydgenote van die vreemde groepie mense hulleself seker afgevra.

Hardnekkig, dwarskoppig met haas ongelooflike "dopperse" halstarrigheid het hierdie mense aan 'n ideaal vasgehou, was hulle bereid om veel ter wille daarvan op te offer. Sou hierdie tipe van moed by die huidige generasie studente en akademici ontbreek? Wat het van die idealisme geword om dwars teen die stroom van sekularisme, professionalisering, spesialisering, kwantifisering en rasionalisering ' $n$ eie standpunt te stel en duidelik en onomwonde prioriteite te bepaal - ook al beteken dit finansiële offers ...?

\section{VERWYSINGS}

BELL, Daniel. 1966. The reforming of general education; the Columbia College experience in its national setting. New York: Columbia Univ. Press.

CALVIN COLLEGE. 1970. Christian liberal arts education; report of the Calvin College Curriculum Study Committee. Grand Rapids.

DAWSON, Christopher. 1961. The crisis of Western education. New York: Sheed and Ward.

GRANT, George. 1975. The university curriculum and the technological threat. (In: Niblett, Roy, red. The sciences, the humanities and the technological threat. Iondon: University of London Press.) 
MARX, Leo. 1975. Technology and the study of man. (In: Niblett, Roy, red. The sciences, the humanities and the technological threat. London: University of London Press.)

MEYER, A.M.T. 1969. Die wetenskap as ontwerp. Pretoria: Academica.

ROSZAK, Theodore. 1969. red. The dissenting academy. London: Chatto \& Windus. 